\title{
Longing for Health. A Practice of Religious Healing and Biomedicine Compared
}

\author{
Sipco J. Vellenga
}

Published online: 1 May 2008

(C) Blanton-Peale Institute 2008

\begin{abstract}
The standard notion is that biomedicine and religious healing are two completely different practices in modern Western societies. In this article, this notion is questioned by comparing in the Netherlands one practice of religious healing, namely the 'Services of salvation and healing' of the Pentecostal Levensstroom gemeente (Livingstream Church) of Jan Zijlstra, and one practice of biomedicine, namely the Antoni van Leeuwenhoek Cancer Hospital (AvL). What are the differences and possible similarities between these two? Starting from a cultural approach and after the description of these two practices, they are compared with respect to four points: concepts and objects, means and methods, 'healers' and patients, and effects and expectations. It is argued that these practices have at least five principle points in common: a tendency to objectivation of the underlying framework, a very instrumental way of working, 'healers' with a high ascribed status, efficacy along the indirect line of symbolic healing, and a comparable way of dealing with unknown and uncontrolled forces. What can these practices learn from each other?
\end{abstract}

Keywords Religious healing practices - Biomedical practices · The Netherlands

\section{Introduction}

A widespread notion in social sciences and in Western public opinion as well, is that in modern societies biomedicine and religious healing are two totally separated and completely different spheres. Biomedicine is based on a distinctive body of scientific knowledge and tries to tackle health problems by medical and pharmaceutical intervention, while religious healing is founded on specific notions that supernatural forces are able to intervene in the body of an ill person. Separate specialists are appropriated to each practice. The separation of biomedicine and religious healing is considered to be the final result of

\footnotetext{
S. J. Vellenga $(\bowtie)$

Religious Studies, Faculty of Humanities, University of Amsterdam, Oude Turfmarkt 147, 1012 GC Amsterdam, The Netherlands

e-mail: s.j.vellenga@uva.nl
} 
the societal process of differentiation which began in the Middle Ages and has proceeded rapidly especially after about 1850 (McGuire 1986, 1994).

The aim of this article is to question the general notion that biomedicine and religious healing are two diametrically opposite practices. The central question is what the differences and similarities are between these two. In order to answer this question, I want to carry out an empirical inquiry focussed on two specific practices. As known, there are many types of religious healing, like there are many branches of biomedicine. In the West, religious healing includes, among others, Protestant faith healing, Catholic devotional healing, Islamic folk healing, and many forms of Esoteric healing, ${ }^{1}$ while biomedicine and hospitals are divided into many parts and divisions, such as oncology and neurology, surgery and revalidation. ${ }^{2}$ This article focuses on two particular practices in the Netherlands, namely the 'Services of salvation and healing' of the Pentecostal Levensstroom gemeente (Livingstream Church) of Jan Zijlstra in Leiderdorp ${ }^{3}$ and the Antoni van Leeuwenhoek Cancer Hospital (AvL) in Amsterdam. ${ }^{4}$ The first mentioned practice stands in the tradition of faith healing within Pentecostalism and the last mentioned practice is an internationally acknowledged top center of oncology.

I compare and contrast these two practices with respect to four basic aspects:

- concepts and objects (In which terms do they define illness and healing? What are their underlying, unspoken assumptions? What do they consider as the main goal(s) of their practice?)

- means and methods (How and by which means do they try to attain the objects? Which diagnostic methods and treatments do they apply?)

- 'healers' and patients (What is the position and the role of the 'healer'? What is the interaction pattern between the 'healer' and the patient?)

- effects and expectations (What are the effects of the practices on patients and their illnesses? How do these practices deal with therapeutic failure?) (cf. McGuire 1994)

The empirical inquiry consists of seven visits to Zijlstra's healing services in the period of 2005-2007, and five 'observation days' in AvL in May 2007. In addition, I interviewed Jan Zijlstra and two AvL-physicians: Dr. Helgi H. Helgason and Dr. Emiel

\footnotetext{
${ }^{1}$ In fact, the topic of religious healing in the West has never drawn a lot of attention in sociology. The most prominent study about this subject is Meredith McGuire's Ritual Healing in Suburban America (1994), which shows that ritual healing is a widespread phenomenon in middle-class America. Some other publications about religious healing in Western society are Martin and Vaux (1982), Fuller (1989), Allen and Wallis (1993), Hinnells and Porter (1999), and Barnes and Sered (2005).

${ }^{2}$ Nevertheless, the interest in Hospital Ethnography is growing exemplified by the publication of a special issue of Social Science \& Medicine about this issue (Van der Geest and Finkler 2004), until now only a few ethnographic studies have paid attention to the possible similarities between religious healing and biomedicine in the West, or more specifically, to the religious dimension of medicine and hospital work. Interesting contributions are Moerman (1979), Katz (1981), Dow (1986), Welch (2003), and Van der Geest (1994, 2005).

${ }^{3}$ The Levensstroom Church was established by the evangelist Jan Zijlstra in 1992. Zijlstra had been the companion of the revival preacher Johan Maasbach for many years when he quitted the Johan Maasbach Wereldzending (Johan Maasbach World Mission) after conflicts at the end of the 1980s. The Levensstroom Gemeente has been growing steadily since its establishment and moved into a new large building with 1,500 seats in 2005. See: http://www.levensstroom.nl.

${ }^{4}$ The Antoni van Leeuwenhoek Hospital merged with the Netherlands Cancer Institute. The primary objective of this prominent centre is to make a substantial contribution to combating cancer through an intensive interaction between scientific research and clinical application, supported by strong training. The centre accommodates approximately 1,850 employees, 53 specialists, 180 beds, and an out-patients clinic that receives 90,000 patients each year. See: http://www.nki.nl.
} 
J.Th. Rutgers. ${ }^{5}$ During the first two days at the AvL, I attended the six main divisions of the hospital: the nursing department, the centre for clinical research and treatment, the out-patient clinic, the department for day care, radiology and radiotherapy, which offered me an overall picture of the hospital. Next days I observed 30 consults at the policlinic and interviewed five patients. Additionally to the observations and interviews, I studied primary and secondary literature about the two practices.

\section{Approach and Terminology}

Both, religious healing as well as biomedicine are part of a broader cultural context (Cf. Freund and McGuire 1991; Annandale 1998; Turner 1999; Van der Geest 2005). They are based on the fundament of a larger belief system. Religious healing assumes the presence of a supernatural power which can restore the natural order, whereas biomedicine presupposes a natural order that can be studied by natural and biosciences. By technical and pharmaceutical intervention physicians contribute to the restoration of the physical order. These basic beliefs and values are demonstrated and confirmed by the way religious healers, respectively, doctors and nurses do operate. ${ }^{6}$

Both types of healing can be considered as attempts to contribute to the improvement of health. In 1948, the World Health Organisation (WHO) defined the concept of health as 'a state of complete physical, mental and social well-being and not merely the absence of disease or infirmity'. Nowadays this broad definition is also shared by a large part of the Dutch population. According to data of surveys of the Netherlands institute for Social Research (SCP), the Dutch have related the concept of good health even more to 'feeling fit' and 'psychological balance' than to the absence of a disease since the 1980s (Van Campen 2007).

In order to specify the medical object of religious healing and biomedicine, it makes sense to make a distinction between 'disease' and 'illness' and related to that between 'curing' and 'healing'. 'Disease' is a biophysical event; it refers to physical disorder or infirmity and is the prime concern of medical practitioners, whereas 'illness' refers to the way in which sick people define and experience the state of their health. In this context, the term 'curing' refers to recovering from disease and 'healing' to the improvement of the way persons experience their health or sickness (Helman 1984). ${ }^{7}$ Both terms can be meaningfully distinguished. Through palliation, for example, patients can feel much better while the disease is still there, and conversely, people can remain feeling tired, sick, and exhausted despite the fact that the disease has been expelled by a medical operation. Nevertheless, healing and illness are strongly interwoven. Healing can be the catalyst for the process of curing a disease and conversely, curing can be beneficial to healing. If sick

\footnotetext{
5 I gratefully acknowledge all three for their collaboration and openness.

${ }^{6}$ Related to this issue, I question the remark of the social historian of medicine Roy Porter made in an article on 'Religion and Medicine' that scientific medicine is unable to give any meaning (1993; cf. Kleinman 1993). I consider both religious healing practices as well as scientific medical practices as expressions and demonstrators of particular meaning systems. Nevertheless, these meanings systems differ in scope. Whereas the scope of the medical meaning system is limited to primarily the physical health situation of sick people, the religious meaning system refers to life as such and even reality as a whole.

7 Bryan Turner points out that not only 'illness', but also 'disease' is not a natural fact but essentially a cultural phenomenon, or, in other words, a product of processes of meaning and classification. He writes "Disease is not a unitary concept and not simply a factual statement about natural processes; it is a classification reflecting both material and ideal interests" (1999, p. 214).
} 
persons feel better, their curing process will most likely be positively stimulated and if patients are cured from a disease, they usually will start feeling better.

\section{Jan Zijlstra's Healing Service}

At least twice a month at Saturdays and Sundays the Levenstroom healing service takes place in a brand-new church building at the industrial area. Jan Zijlstra is on stage in front of the hall and he calls himself a 'servant of God' and explicitly not a 'faith healer'. He explains: "God heals, I don't, I am just his instrument." The hall is filled with hundreds of people. Many of them point out to be there for the first time. When visitors enter the building, they are given a warm welcome by volunteers of the Levensstroom Church. After singing a few simple songs of praise, which are projected on a screen and accompanied by a band, Zijlstra starts with a prayer in which he presents God as almighty and close by. "God is the Almighty ... God wants to be our father ... He wants to change your life tonight." After some announcements, a testimony of a miracle and a call for donations, the preacher gives an explanation of some scripture verses. During the service Zijlstra creates the expectation that people can be healed that same evening if they are willing to accept Jesus in their hearts as their Saviour and Lord. His message is that healing is not available separately but is indissolubly linked to a personal relationship with Jesus Christ and reading the Bible faithfully as well. The sermon is followed by the so-called 'altar call' in which those who want to make a spiritual commitment to Jesus Christ are invited to come forward. Approximately 50 people gather around the stage. Zijlstra prays and finishes with the words: "I proclaim that the power of sin has been broken in your life. You are free. To each of you I say, welcome to the family of God. We are brothers and sisters in the Lord". The audience applauds. Deacons of the Levenstroom Church take the new converts for aftercare backstage, to the canteen of the building. Then the main part of the service starts: the ministry of healing. Many people with different kinds of afflictions and ailments come forward and are queuing up. Zijlstra touches them all one by one and emotions are expressed. During the ritual of laying on of hands he prays for the patients and quotes biblical verses that show that God will heal them to a woman with breast cancer he says: "In the name of Jesus Christ, heal! I break the yoke of cancer in your life. Recover and be healed. The power of Jesus is with you and the cancer will immediately die in your body." After the prayer he asks the sick persons if they already notice recovery. "Has your pain already disappeared?", he asks a woman who suffers rheumatoid arthritis. He shakes her arms and hands and the woman nods. Another patient with arthritis has to demonstrate her healing by running along the aisle of the church. After the laying on of hands ceremony helpers of Zijlstra take care of the sick who came to the front. When all of them went past Zijlstra, the service is rounded off by a prayer of thanks and singing of a final hymn. Every visitor is invited to come back and to join the next service.

\section{The Practice of the AvL-Hospital}

The AvL-hospital is a specialized centre which is aimed at combating cancer. In 2003, it moved to a new accommodation in Amsterdam with all the latest facilities. When a patient enters this hospital for the first time, he/she has to report to the reception for registration before the intake consult will take place in a separate room. On the basis of the anamnesis together with a first clinical examination, the specialist makes a diagnostic plan and 
discusses this with the patient. A physician tells a woman whom he assumes has breast cancer: "I suggest to do a blood test, to make a mammography, a puncture and a MRI-scan", and then explains why he recommends these methods. The diagnostic examination itself is usually a rather technical event in which practitioner and patient hardly communicate. The physician discusses the results of the diagnostic tests in a multidisciplinary team. Subsequently, the doctor presents a treatment plan to the patient on the basis of all available information. The patient must agree with this plan before it can be executed. This rule is called 'informed consent'. Because the conversation is precarious and sometimes very confronting, patients are recommended to take relatives with them for support and advice. Yet some patients visit the hospital alone, while others are joined by four or five relatives or fiends. The proposed treatment can be curative (directed to curing), adjuvant (directed to prevent further metastases), and/or palliative (directed to relieving the symptoms caused by the cancer or the treatment of it). The treatments often consist of a combination of surgery, chemotherapy, hormone therapy, and/or radiotherapy. Because all these methods have harmful effects, such as tiredness, hair loss, and nausea, every treatment proposal has essentially the character of a dilemma. Sometimes, a physician is not able to suggest a curative treatment and has to tell the patient that his/her situation seems to be hopeless from a medical point of view. A specialist says to a women with a fatal disease: "I try to be fair. I can not make things better than they are, unfortunately I cannot take away the metastases. I can operate on your left breast and reduce the chance it will trouble you again. I am sorry, but I can not guarantee you more." After a treatment new consults follow. Because it is not certain whether the treatment has taken away all the cancer cells definitely, continuing monitoring remains significant. Only in very specific cases, for example when a patient becomes very depressed during the process of treatment, a psychologist is involved in the care of the patient. Pastoral workers are not used to having contact with outpatients, their work is limited to guiding and counselling internal day care patients.

\section{Concepts and Objects}

Zijlstra's healing services are based on a set of beliefs in which such notions as God, the Devil, Jesus, sin, Bible, faith, and choice are central (cf. Wacker 1986; Allen and Wallis 1992; McGuire 1994). According to this dualistic framework, there is a battle going on between the forces of Good and the forces of Evil, between God and Satan. This struggle manifests itself in the body of ill people. That's why illness is more than just a physical problem; essentially, it is a religious problem. While God is good and will heal, Satan is bad and the deepest root of all illness. Although people are separated from God due to the Fall from Eden, they can get a relationship with Him when they accept Jesus in their life as their Lord. Jesus defeated the Devil on Golgotha and will free people not merely from sin but also from their diseases and illnesses.

The Levensstroom services are aimed at healing illnesses as well as curing diseases. People with very different kinds of ailments come to these meetings for help, such as asthma, diabetes, rheumatism, infertility, and cancer. The process of becoming closer to God is considered to be the key condition of healing. Zijlstra believes and proclaims that without a personal relationship, people cannot experience the curing and healing power of God. That is the reason why the 'altar call' always precedes the ministry of healing.

The members of the medical team from the AvL do not define physical health problems from a religious perspective, but mainly in physical terms. They consider them primarily as 
the result of relatively autonomous biological and biochemical processes in the body of the patient. Doctors tell patients about their cancer diseases in biological terms, such as (uncontrolled) cell division, tumours, drugs, activators, enzymes, genes, and metastasis. Among themselves they use a specific jargon in which, for example, breast cancer growing in the lobes of the breast is called 'lobular carcinoma' and drugs suppressing abnormal cell division 'cytostatics' or 'anti neoplastic agents'.

The aim of the AvL is to combat cancer and to alleviate the symptoms of this disease. In order to realize these objectives, the AvL prefers to apply exclusively scientifically proved curative and palliative treatments. Due to the fact many types of cancer, certainly in a far advanced stage, cannot be treated completely and definitively, and, moreover, the seriously harmful side effects of many treatments, doctors use to talk in terms of 'chances' and 'risks', 'advantages' and 'disadvantages', 'short-term' and 'long-term' prospects. After a doctor makes up a treatment plan, he/she will discuss it with the patient. When the patient agrees with the proposal, according to the rule of 'informed consent', it will be executed.

The AvL is sceptical about alternative, non-scientifically based treatments of cancer. The institute considers them unreliable. In the most positive case they are means that can improve the way patients experience their diseases. A brochure of the Dutch Cancer Society, distributed by the AvL, says: "It is the opinion of the Dutch Cancer Society that every treatment must be tested scientifically, before we can assess that it ha0s a positive effect on a disease. If this effect is not (yet) proved, an additional therapy beside a regular therapy can be yet important for the patient, e.g. because someone feels better if he/she is actively involved in the process of healing, or because someone believes that the additional treatment supports his/her recovery."

\section{Means and Methods}

Nevertheless, Zijlstra does not use instruments in his services, these services are systematically and instrumentally ordered and directed to the ministry of healing. The object of his services is the experience of the healing power of God. In order to achieve this goal, every worship starts with singing simple, rhythmic songs which helps the churchgoers to make the transition from 'outside' to 'inside'. In an informal atmosphere, this part is followed by prayers, new songs, witnesses, music, and a sermon, aimed at reactivating the faith of the believers and preparing potential converts for the 'altar call'. Finally, this event is followed by the ministry of healing, in which Zijlstra lays his hands on patients praying that God will heal them.

In the services Zijlstra does not diagnose diseases. That is unimportant because God is considered to be the medicine for all diseases. The seriousness of a disease is only mentioned to raise the expectations and to indicate how mighty God is. "God can even heal cancer." In fact the diagnosis is insignificant as God's healing power is viewed as the answer to all medical problems.

The healing services have the structure which the anthropologist James Dow recognizes in general in symbolic healing practices: (a) The healer and healed share a general cultural mythic world; (b) The healer persuades the patient that the problem can be defined in terms of the shared myth; (c) The healer attaches the patient's emotions to transactional symbols particularized from the general myth; and (d) The healer manipulates the transactional symbols to help the patient transact his or her own emotions (1986; cf. Van der Geest 2005). Zijlstra starts with a sermon and an 'altar call' by which he articulates and creates a shared cultural, or more specific, religious myth. Then, he redefines the physical problems 
of patients in terms of this religious myth and attaches the patients' emotions to the key symbols of this myth, in particular the myth of "Jesus". Subsequently, he manipulates these symbols by saying for instance: "Be healed in the Name of Jesus. In his name there is forgiveness of sin and healing of the body." These words can touch patients deeply and promote the transformation of their emotions. According to Dow's theory, this transformation can have a strong impact on the way patients experience their illness and finally also on their biophysical condition.

Within the AvL, physicians do not accomplish healing by praying or laying on of hands, although there is physical contact when, for example, a doctor examines a patient physically or a doctor pats a patient on the back to encourage him or her. They primarily try to improve patients' health by carrying out extensive diagnostic tests and applying highly sophisticated treatments. Specialists have access to a wide range of technology and advanced diagnostic and therapeutic instruments. Their conviction is that by using these tools diseases can be diagnosed most precisely and treated most effectively. The AvL has the ambition to play a leading role in new developments in the fight against cancer. Hence the department of radiotherapy, for instance, uses one of the latest types of irradiation equipment, the cone beam computerised tomography linear electron accelerator. With this equipment, the clinician can view a three-dimensional scan of the patient during irradiation, which makes it possible to target tumours that move with high precision and high radiation doses.

Indeed, the use of such advanced techniques has a symbolic meaning too. It provides the patient the feeling that his or her disease is treated very carefully and all available human knowledge and means are applied to improve his or her situation. If James Dow is right, stating that positive manipulation of emotions can affect psychological processes and ultimately also physiological processes in an individual, than this 'psychology of medical technique' contributes to the process of healing and recovering (Dow 1986). Then the therapeutic efficacy of the use of high-tech medical instruments is not merely produced by the technical effects of these instruments, but also co-produced by the positive emotions that they evoke among patients (cf. Welch 2003; Van der Geest 2005).

\section{'Healers' and Patients}

In the Levenstroom Church Jan Zijlstra is the central figure. He is the founder and the minister of this church. In the services all eyes are focussed on him. He is considered to be an intercessor between the ill person and the healing God. His style of operating is quite rational. Not only does he make a strong appeal to the audience to contribute financially to the church, but he also leads the services very orderly. Moreover, on stage he talks in a quite rational way to patients. Zijlstra: "What is your problem?" A sick woman: "I have a whiplash." Zijlstra: "Do you believe God can perform a miracle and heal you tonight?" The woman replies: "Yes, sure I do." Zijlstra puts his hands on her forehead and says: "Do you feel God's power is on you? In the name of Jesus: your nerves are renewed." And a little later: "Where is your pain? Is it gone?" Zijlstra is surrounded by a team of assistants. His authority in the church community seems to be primarily based on the belief that God called him to do this work of healing. According to the website of the Levenstroom Church, God called him for the ministry of healing in 1991. In his church Zijlstra has the status of a charismatic leader in the sense Max Weber coined this term, a person who is considered by his adherents to be endowed with special qualities and supernatural gifts (Weber 1978). 
In the 'primary process' of the AvL the doctor is the most prominent figure. His authority is not based on supposed charismatic qualities, as in Zijlstra's case, but mainly on medical expertise. Nevertheless, doctors are not just ordinary experts. Based on the law, they are authorised to use medical and pharmaceutical means that can possibly improve or worsen patients' health. In fact they have a special authority over matters of health, life, and death what gives them a particular status (Good 1994). In addition to the quality of medical expertise, optimism, empathy, and confidentiality are important. During consults doctors tell their patients about their medical situation and discuss the prognosis of the development of the disease. Subsequently, they recommend what would be the best treatment from their point of view. One of the doctors says: "In my contact with patients I use five guidelines: openness, commitment, transparency, expertise, and the creation of the suggestion to have plenty of time." It is remarkable that, nevertheless, the diagnoses of cancer evokes strong feelings of uncertainty and deep existential questions by many patients, the hospital psychologists and pastoral workers do not play a significant role in supporting patients. Usually, they only have contact with day care patients and not with outpatients. Only in exceptional cases, for example when patients become very depressed by the desperate prognosis of their disease, hospital psychologists are involved. ${ }^{8}$

\section{Effects and Expectations}

What the healing effects are of one or more visits to Zijlstra's healing services is difficult to assess. There are examples of miraculous healings in which patients recover unexpectedly after a visit to these meetings (Zijlstra 2002). A recent example is the healing of Janneke Vlot who suffered a post-traumatic dystrophy for a long time and healed miraculously during the healing session on March 4, 2007 (Reformatorisch Dagblad, March 30, 2007). It is impossible to determine if this healing was a 'spontaneous natural healing' or a 'supernatural healing'. But it is clear that these kinds of healings take place rather seldomly and the overwhelming majority of the sick who attend Zijlstra's services do not recover immediately from their diseases after their visit. However, this does not mean that these services do not have a strong impact on them. They offer attendees attention and support as well as an encompassing framework which can help them to cope with their problems. It is my strong impression, that many people feel better by a visit to those services. In other words, they empower people. Although Zijlstra's services seldom lead to the curing of a disease, it will probably contribute to healing and the well-being of the sick. ${ }^{9}$

During the services, Zijlstra only tests the medical effects of the ritual of laying on of hands marginally. He asks patients immediately after the ritual if they have already noticed recovery and subsequently to demonstrate this to the audience. A muscular dystrophy patient who sits in a wheelchair has to stand up and walks on stage. He requests an asthma patient to run along the church aisle. These demonstrations are greeted by the audience with applause and functions, as Meredith McGuire pointed out, within a 'dissenting' Church such as Zijlstra's, as a sign of the truth of the collective confessed belief (1993).

\footnotetext{
${ }^{8}$ In the Netherlands, currently about 850 spiritual care givers work in health care institutes, such as general or psychiatric hospitals, nursing homes or centers for the mentally handicapped. They are paid by the state. Their main task is to offer patients guidance in seeking meaning and orientation in their situation.

9 Interesting literature on religion as a source of empowerment is: Levin (2001); Koenig and Larson (2001); Harrison et al. (2001).
} 
It is notable that the practice of the Levensstroom Church provides little support to chronically ill people in terms of content. Zijlstra does not present God as inscrutable or as the Comforter, but calls upon churchgoers with long-term illness to persist in their faith and continue soul-searching. In the imagery world of the Levensstroom Church, six 'parties' are involved in healings: God who wants healing; Satan who is the root of illness, Zijlstra who transmits God's healing power, the sick persons, their partners, families and friends, and the church community. It is worth noticing that in fact Zijlstra puts all responsibility for therapeutic failure on the shoulders of the sick. Insufficient faith, the presence of blockage of sin, lack of openness to God are considered to be the main obstacles for healing (Zijlstra 2000). By doing so, he puts an extra burden on their shoulders.

The effectiveness of curative treatments in the AvL depends to a high degree on the type and the growth stage of the tumour. Merely with regard to breast cancer, already five subtypes can already be distinguished. Usually testicle cancer can be treated effectively by chemotherapy, while for instance kidney cancer, especially with metastasis, can hardly be treated curatively. It is known, that the effectiveness of adjuvants and palliative treatments varies as well. While the chance on recidivists in breast cancer can often be reduced to $50 \%$, with regard to lung cancer this percentage is much lower. AvL-physicians expect that the effectiveness of cancer treatments will increase the coming years substantially due to the combination of 'old' types of chemotherapy and new anti-cancer drugs.

AvL-physicians try to avoid creating false expectations regarding the efficacy of a therapy. In many cases, the effectiveness of a specific treatment is not exactly known. Doctors know the effectiveness of a treatment in general, but not with regard to a particular individual patient. Partly because of this uncertainty and the damaging side effects of treatments, physicians prefer to speak in terms of 'chances' and 'risks' and 'short-', and 'long-term' effects.

If recovering is excluded, patients are used to receiving palliative treatments in order to make their lives as 'comfortable' as possible for the time that remains. Patients who are in a good condition are sometimes invited to participate in research projects directed to test the effectiveness of new treatment methods or medicines.

\section{Final Remarks}

The standard picture is that biomedicine and religious healing are two completely different practices in modern times. Is this image tenable when we apply it to the relation between the practices of Jan Zijlstra's and the AvL? In other words, are these two practices totally different or are there some similarities between them also.

It is obvious that these two practices differ strongly with respect to many points: they start from different perspectives, they are based on different concepts, they use different methods and techniques, they are carried out by different types of 'specialists', they have different effects on patients and they are in a different way dealing with problems of hope and despair. However, despite all these differences, we found that they have also a few interesting characteristics in common. I focus on each of the four basic aspects of the practices.

\section{Concepts and Objects}

Both healing practices start from a particular framework. It is remarkable that both deal with these frameworks in the same way, in the sense that both consider them as unquestionably true. We can talk of 'objectivation' or 'naturalisation' (Durkheim 1995; Berger 
and Luckmann 1976; Van der Geest 2005). These frameworks attain the character of objectivity, are set apart and are placed above any criticism. They are conceived not as interpretations of reality, but as reality itself. In the Levenstroom Church, Zijlstra's message of hope and healing has the status of the Truth, and in the AvL the diagnosis made by the specialist has the status of a fixed fact. Alternative interpretations are not taken seriously if they are not scientifically based. "Medical words and interventions express and re-create people's belief in the canons of science and biomedicine as ultimate truth."(Van der Geest 2005, p. 135) In both practices patients concur with the frameworks, during the 'altar call' or the procedure of 'informed consent', before the treatment is executed. Agreement with the 'myth' precedes participation in the 'ritual'.

\section{Means and Methods}

It is notable that not only the AvL-physicians but also Zijlstra and his assistants work in a very instrumental or 'goal rational' way. Their work is aimed at healing by the encounter with God and the whole structure of the services as well as the performance of Zijlstra is directed to attaining this goal. In his book The Wounded Storyteller, the sociologist Arthur Frank distinguishes three types of illness narratives: the restitution narrative, the chaos narrative, and the quest narrative (1995). What is visible, is that in both practices the restitution narrative is dominant. This narrative has the basic storyline: "Yesterday I was healthy, today I'm sick, but tomorrow I will be healthy again." Both do not accept illness, but attempt to restore health with the help of external forces and means. If healing in medical terms is not an option anymore, elements of the quest narrative are recognizable in the AvL-practice. AvL-physicians invite ill persons to face their situation fairly and, at the same time, assure them that they will do everything they can to alleviate the symptoms of their diseases. ${ }^{10}$

\section{'Healers' and Patients}

Both, Zijlstra and the doctors of the AvL enjoy a high status. Zijlstra is considered by his followers to be endowed with God-given gifts, while the patients of the AvL are aware that their health depends on the decisions made by doctors. Only doctors are allowed to use medical means and dependent on their choices patients' situation will possibly improve or deteriorate. They are not only hardworking and expert professionals, but also, just like Zijstra, messengers of hope with regard to matters of life and death. In fact their work has a, in Byron Good's terminology, soteriological aspect. Doctors are not merely technicians repairing a machine, but at the same time, bringers of salvation (Good 1994).

\section{Effects and Expectations}

It is noticeable that both practices work partly in the same way. It is clear that in contrast to Zijlstra's practice, the AvL tries to improve the physical health situation of patients directly by biomedical intervention. However, next to this, both Zijlstra's practice as well as the AvL affect the health condition of patients along the same indirect line of 'symbolic healing'. According to Dow's model of symbolic healing, Zijlstra contributes to the health

\footnotetext{
${ }^{10}$ I did not find elements from the chaos narrative in the approach of both practices. This narrative is the opposite of the restitution narrative: it lacks any coherence and states that treatment does not make sense (Frank 1995).
} 
of patients by manipulating key symbols in patients' Pentecostal belief system (1986). By doing so he restores patients' cognitive and emotional order. Because order restored on one level can 'infect' the restoration of order on other levels, this positive intervention can contribute to the process of recovery. In the same way, the AvL-practice also stimulates the process of recovery. The performance of specialists, their words, gestures and technomedical acts, and the machinery of the hospital also manipulate the emotions of patients. They create confidence and hope which enlarges the total therapeutic effect of the AvL-practice (cf. Welch 2003; Van der Geest 2005).

Besides, both practices are dealing in a comparable way with unknown and uncontrolled forces. This element is not only recognizable in Zijlstra's religious practice, but also in the AvL. Although AvL-doctors are able to combat many health problems effectively, there are still many problems they are not able to solve, or, in other words, which are out of their control. Noticeably, in the Levenstroom-practice as well as the AvL-practice the 'uncontrolled' is linked to human deficiency. Zijlstra talks about this in terms of lack of faith or sin, while in the AvL it is linked to the deficiency of human knowledge. Consequently, Zijlstra calls upon ill persons to persist in faith and to confess their sins, while in the AvL hopes are pinned on further scientific research and new scientific breakthroughs.

Finally, just one question: What can these two types of practices learn from each other? Because healing seems to be the rule and curing the exception in the faith healingpractices, it is desirable that faith healers temper the expectation on medical healing in the services. It would be wise to inform patients that the statistical chance of permanently healing an organic medical disease is minute and it would be merciful to give chronically ill persons more support in content than currently is the case.

The growing popularity of religious healing practices exemplified by Jan Zijlstra's practice indicates that many patients do not only need medical care, but are also longing for psychosocial and spiritual support. A serious disease has a strong impact on patients' lives in many respects. Beside its practical consequences, it can disturb the experience of one's own body, puts intimate relationships under strain and collapses images of the future. Religious healing practices meet these needs by giving patients attention and support and framing their situation in a broader perspective on life as such. In a comparable way spiritual care givers in a hospital setting can answer these needs. Consequently, the growing popularity of ritual healing practices appeals to health care organisations which intend to deliver patient-oriented care to meet these psychosocial and spiritual needs more sufficiently than they do at this moment and to invest in patient support units-comprising psychologists, social workers, and spiritual care givers.

Open Access This article is distributed under the terms of the Creative Commons Attribution Noncommercial License which permits any noncommercial use, distribution, and reproduction in any medium, provided the original author(s) and source are credited.

\section{References}

Allen, G., \& Wallis, R. (1992). Pentecostalists as a medical minority. In M. Saks (Ed.), Alternative medicine in Britain (pp. 154-165). Oxford: Clariton Press.

Annandale, E. (1998). The sociology of health and medicine. A critical introduction. Cambridge etc.: Polity Press.

Barnes, L. L., \& Sered, S. S. (Eds.). (2005). Religion and healing in America. Oxford/New York etc.: Oxford University Press. 
Berger, P., \& Luckmann, T. (1976). The social construction of reality. A treatise in the sociology of knowledge. Middlesex etc.: Penguin Books.

Dow, J. (1986). Universal aspects of symbolic healing: A theoretical synthesis. American Antropologist, 88, 56-69.

Durkheim, E. (1912/1995). The elementary forms of religious life (K. E. Fields, Trans.). New York etc.: The Free Press.

Frank, A. W. (1995). The wounded storyteller. Body, illness, and ethics. Chicago/London: The University of Chicago Press.

Freund, P. E. S., \& McGuire, M. B. (1991). Health, illness and the social body. A critical sociology. Englewood Cliffs, NJ: Prentice Hall.

Fuller, R. C. (1989). Alternative medicine and American religious life. Oxford: Oxford University Press.

Good, B. J. (1994). Medicine, rationality and experience. An anthropological perspective. Cambridge: Cambridge University Press.

Harrison, M., Koenig, H. G., Hays, J., Eme-Akwari, A., \& Pargament, K. I. (2001). The epidemiology of religious coping: A review of recent literature. International Review of Psychiatry, 13, 86-93.

Helman, C. G. (1984). Culture, health and illness. Oxford: Butterworth Heinemann.

Hinnells, J. R., \& Porter, R. (Eds.). (1999). Religion, health and suffering. London/New York: Kegan Paul International.

Katz, P. (1981). Ritual in the operating room. Ethnology, 20, 335-350.

Kleinman, A. (1993). What is specific to Western medicine? In W. F. Bynum \& R. Porter (Eds.), Companion encyclopedia of the history of medicine (pp. 15-23). London and New York: Routledge.

Koenig, H. G., \& Larson, D. B. (2001). Religion and mental health: Evidence for an association. International Review of Psychiatry, 13, 67-79.

Levin, J. (2001). God, faith and health. Exploring the spirituality-healing connection. New York: John Wiley \& Sons.

Marty, M. E., \& Vaux, K. L. (Eds.). (1982). Health/medicine and the faith traditions. An inquiry into religion and medicine. Philadelphia: Fortress Press.

McGuire, M. B. (1986). Religion and healing. In P. E. Hammond (Ed.), The sacred in a secular age. Towards revision in the scientific study of religion (pp. 268-284). Berkeley etc.: University of California Press.

McGuire, M. B. (1993). Health and spirituality as contemporary concerns. The Annals of the American Academy of Political and Social Science, 527, 144-154.

McGuire, M. B. (1994). Ritual healing in suburban America. New Brunswick: Rutgers University Press.

Moerman, D. E. (1979). Anthropology of symbolic healing. Current Anthropology, 20(1), 59-80.

Porter, R. (1993). Religion and medicine. In W. F. Bynum \& R. Porter (Eds.), Companion encyclopedia of the history of medicine (pp. 1449-1468). London and New York: Routledge.

Turner, B. S. (1999). The body \& society. Explorations in social theory. London etc: Sage Publications.

Van Campen, C. (2007). The importance of being healthy: Changing views on the 'good life' in the Netherlands since 1945. In J. Stam \& R. Veenhoven (Eds.), Analysis of the quality of life and happiness of people: Japanese and Dutch societies compared (pp. 62-71). Amsterdam: KIT/Hotei Publishing.

Van der Geest, S. (1994). Christ as a pharmacist: Medical symbols in German devotion. Social Science \& Medicine, 29(5), 727-732.

Van der Geest, S. (2005). 'Sacraments' in the hospital: Exploring the magic and religion of recovery. Anthropology \& Religion, 12(2), 135-150.

Van der Geest, S., \& Finkler, K. (Eds.) (2004). Hospital ethnography [Special issue]. Social Science \& Medicine, 59(10), 1995-2108.

Wacker, G. (1986). The pentecostal tradition. In R. L. Numbers \& D. W. Admundsen (Eds.), Caring and curing. Health and medicine in the western religious traditions (pp. 514-538). New York/London: MacMillan Publishing Company.

Weber, M. (1920/1978). Gesammelte Aufsätze zur Religionssoziologie. Tübingen: J.C.B. Mohr.

Welch, J. S. (2003). Ritual in western medicine and its role in placebo healing. Journal of Religion and Healing, 42(1), 21-33.

Zijlstra, J. (2000). 50 Hindernissen op de weg naar genezing [50 Obstacles on the way to healing]. Leiderdorp: De Levensstroom.

Zijlstra, J. (2002). Wonderen. Ze gebeuren nog steeds [Miracles. They still happen]. Leiderdorp: De Levensstroom. 